\title{
Eco-Alcocenoses of Fish Ponds in the Samarkand Region and its Ways of Formation
}

\author{
Shavkat Shukhratovich Shernazarov* \\ Department of Biotechnology, Samarkand Institute of Veterinary Medicine, \\ Samarkand, Uzbekistan \\ *Corresponding author
}

\begin{abstract}
A B S T R A C T
Keywords

Algoflora, fish ponds, species, algocene formations, environmental factors

Article Info

Accepted:

15 June 2021

Available Online:

10 July 2021

Today it is important to provide the population with cheap, high-quality and environmentally friendly food, to maintain the sustainability of biodiversity in artificial reservoirs, especially to strengthen the food base for the development of the fishing industry. In this regard, the preservation and enrichment of the biological diversity of artificial reservoirs, ensuring the natural development of hydrobionts and increasing the productivity of fish using inexpensive, environmentally friendly methods are among the most important tasks today. Therefore, it is important to determine the hydrobiological characteristics of artificial fish ponds, determine the current state, conduct an inventory and identify patterns of algoflora formation.
\end{abstract}

\section{Introduction}

Algological studies all over the world are aimed at determining the state of algoflora in artificial reservoirs in areas with a strong anthropogenic impact on the assessment of quantitative and seasonal characteristics of feed algae in fish ponds in order to provide the population with cheap, high-quality and environmentally friendly fish products. It is especially important to preserve the biodiversity of artificial reservoirs in densely populated areas, ensure its sustainability, and develop effective technologies for using local and environmentally friendly food products when growing fish products. In this regard, in fish ponds with various food sources, which determines the increase in the productivity of herbivorous fish by determining their hydrobiological properties, studying seasonal and quantitative aspects of algoflora and on this basis increasing the biomass feed algae species and reduce harmful species. Accordingly, the study of the composition of the algoflora of fish ponds, the justification of the role of environmental factors in the formation of algoflora in it, the development of recommendations for use in the field to 
increase fish productivity by assessing the seasonal and quantitative characteristics of herbivorous species is of important scientific and practical importance.

\section{Materials and Methods.}

During the period of research and scientific expeditions (2016-2020), more than 200 (150 phytoplankton, 25 benthos, 25 periphyton) algological samples were collected (Figure. 1). The collection of materials and laboratory analyses were carried out according to generally accepted and modern algological (Gollerbach, Polyansky, 1951). "Taxonomic classification of cyanoprokaryotes (Cyanobacterialgenera) 2014"was used to systematize blue - green algae. Diatoms are systematized according to the "System class Fragilariophyceae Round emend. Gogorev et Stepanova (Bacillariophyta)", K. Kgammeg, H. Lange-Bertalot (2011). The systems proposed by M. S. Kulikovsky et al., (2016), euglenic " Higher classification and phylogeny of Euglenozoa (2016)", dinophytes "On dinoflagellate phylogeny and classification (2007)", green algae " Systematics of the green algae: conflict of classic and modern (2008)", "The taxonomy of the Chlorophyta" (2007) were also used. The general analysis of taxa was carried out according to V. Schmidt (1974). When analyzing the ecological and geographical features of algae, widely used works of a number of authors were used (Tashpulatov, 2017; Tashpulatov, et al., 2020).

\section{Results.and Discussion}

From the studied fish ponds of the Samarkand region, 258 species and varieties (256 species, 2 forms) of algae were identified. According to the analysis, 5 departments were identified (Cyanoprocaryota, Dinophyta, Bacillariophyta, Euglenophyta, Chlorophyta), 10 classes, 31 orders, 59 families, 126 genera
(Table 1). According to the taxonomic analysis, the department of Bacillariophyta is the leading one in terms of the number of species. It includes 97 species and varieties. They account for $37.60 \%$ of the algoflora. The next places were taken by Chlorophyta (70 species, 27.13\%), Cyanoprocaryota (69 species, 26.74\%), Euglenophyta (15 species, $5.81 \%)$, Dinophyta (7 species, $2.72 \%$ ). According to the analysis of the leading taxa, a total of 59 families were identified in the surveyed fish ponds. Of these, 22 (37.28\%) families are the leaders in the number of species.

These families include 179 (69.38\%) species. Among the families, the clear leaders were Oscillatoriaceae (17 species, 6.59\%), Bacillariaceae (16 species, 6.20\%), Fragilariaceae (15 species, 5.81\%), Cymbellaceae (10 species, $3.87 \%$ ). Of the remaining 37 $(30.62 \%)$ families, there are $1-4$ species. Of the 126 genera in the algoflora, 18 were the leading ones. Leading births, account for $14.28 \%$ of the total number of births. In these genera, it turns off $100(38.76 \%)$ species of algoflora. Among them are Nitzschia Hassall (14 species; 5.43\%), Closterium (8 species; $3.10 \%$ ), Cosmarium (7 species; 2.71\%), Phormidium Kützing ex Gomont (7 species; $2.71 \%$ ).

The second part of the chapter is devoted to the floristic analysis of algoflora and the peculiarities of its formation. It was noted that, taking into account the ecological characteristics of fish ponds in the studied territories, the nature of water availability, climate, soil and ground conditions differ significantly from each other.

83 species of algae have been identified in the Akdarya reservoir, which belong to 4 divisions, 8 classes, 24 orders, 36 families and 69 genera (Table 2). Nitzschia Hassall (4 species), Ulothrix (4 species), Cosmarium (4 
species), Spirogyra Turpin ex Gomont (4 species), Oscillatoria Vaucher ex Gomont (3 species) are the leading genera of the algoflora of the reservoir. The 5 leading genera include 19 species (22.89\%). The algoflora of the Akdarya reservoir is dominated by such species as: Oscillatoria limosa C. Agardh ex Gomont, Oscillatoria planctonica Woloszynska, Spirulina meneghiniana Zanardini ex Gomont, Spirulina gomontiana Kützing, Synedra ulna Nitzsch, Navicula crypula. The Akdarya reservoir is located directly in the bed of the Zarafshan River, the formation of the algoflora occurred in the following ways: river $\rightarrow$ reservoir; river $\rightarrow$ collector $\rightarrow$ reservoir; river $\rightarrow$ canal $\rightarrow$ rice fields $\rightarrow$ reservoir; domestic effluents $\rightarrow$ reservoir.

121 species have been identified in the algoflora of the Karasuk reservoir. They belong to 5 departments, 10 classes, 27 orders, 46 families, 84 genera. Lindavia bodanica Eulenstein ex Grunow, Cyclotella meneghiniana Kutzing, Peridiniopsis quadridens (F. Stein) Bourrelly, Peridinium pusillum (Pénard) Lemmermann, Euglena caudata Hübner, Gonium pectoralee species are found in the algoflora. Formation of the algoflora of the Karasu reservoir: mountain streams $\rightarrow$ reservoir; supply channel $\rightarrow$ reservoirs.

127 species were identified in the algoflora of the Pastdargom fish ponds, including 5 departments, 11 classes, 27 orders, 52 families, 100 genera. Nitzschia Hassall (6 species), Euglena Ehrenberg (6 species), Cosmarium Corda ex Ralfs (5 species), Oscillatoria Lemmermann (4 species), Phormidium (Meneghini) Gomont in Bornet (4 species), Fragilaria Lyngbye (4 species), Ulnaria (Kutzing) Compère (4 species),
Phacus Dujardin (4 species), Gomphonema Kutzing (4 species), Gyrosigma Hassall (3 species), Chlamydomonas Ehrenberg (3 species), Closterium Nitzsch ex Ralfs (3 species) Merismopedia Meyen (3 species), Spirulina Turpin ex Gomont (3 species). The formation of the algoflora of the Pastdargam fish ponds occurs in the following order: river $\rightarrow$ channel $\rightarrow$ fish ponds; river $\rightarrow$ stream $\rightarrow$ fish ponds; rivers $\rightarrow$ channels $\rightarrow$ waste water $\rightarrow$ fish ponds.

It was established that 164 species were identified in the algoflora of Kattakurgan fish ponds. They consist of 5 departments, 9 classes, 26 orders, 51 families, 98 genera. The following species are intensively developing in the algocenosis: Melosira varians Agardh, Aulacoseira granulata (Ehrenberg) Simonsen, Odontidium anceps (Ehrenberg) Ralfs in Pritchard, Cocconeis pediculus in the algocenosis, Pseudopediastrum boryanum, Tetraëdron minimum (A. Braun) Hrades The formation of the algoflora of Kattakurgan fish ponds occurs in in the following order: river $\rightarrow$ channels $\rightarrow$ fish ponds.

106 species have been identified in the algoflora of Payaryk fish ponds, which consist of 5 departments, 11 classes, 25 orders, 44 families and 71 species. Spirocoleus fragilis, Leibleinia epiphytica, Calothrix bravissimo, Cyclotella meneghiniana, Discostella stelligera Cleve \& Grunow, Odontidium hyemale (Roth), Peridiniopsis quadridens, Euglena gracilis, Chlamydomonas reinhardtii, Volvox ehrenberg, Willea apiculata were identified in these ponds. The algoflora of the Payaryk fish-breeding ponds is formed in the following order: reservoirs $\rightarrow$ fish-breeding ponds; rivers $\rightarrow$ channels $\rightarrow$ fish-breeding ponds; rivers $\rightarrow$ channels $\rightarrow$ drains $\rightarrow$ discharges $\rightarrow$ fish ponds. 
Fig.1 Map-scheme of fish-breeding ponds of the Samarkand region, where algological studies were conducted

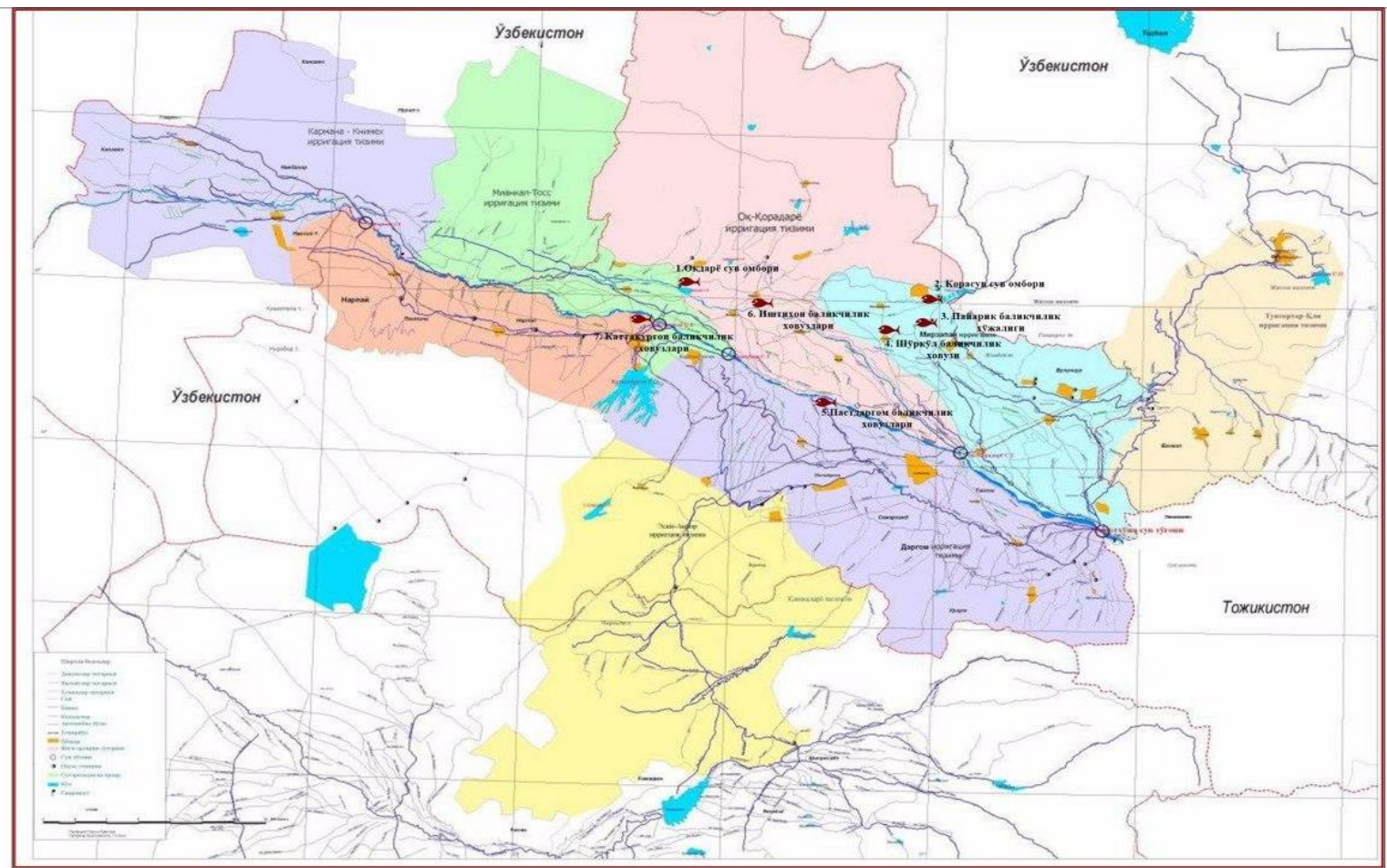

Table.1 Taxonomic composition of algoflora of fish ponds

\begin{tabular}{|c|c|c|c|c|c|c|c|c|}
\hline \multirow[t]{3}{*}{ Division } & \multicolumn{8}{|c|}{ Number of taxonomic units } \\
\hline & & & & & & Variety & & \\
\hline & $\frac{\tilde{z}}{\tilde{u}}$ & $\begin{array}{l}\overline{ \pm} \\
\overline{0}\end{array}$ & 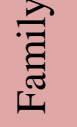 & $\begin{array}{l}\frac{\pi}{0} \\
\stackrel{0}{0} \\
\stackrel{0}{0}\end{array}$ & 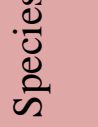 & छ્ర & 完 & $b^{e}$ \\
\hline Cyanoprocaryota & 1 & 5 & 17 & 38 & 69 & - & 69 & 26,74 \\
\hline Dinophyta & 1 & 2 & 2 & 5 & 7 & - & 7 & 2,72 \\
\hline Bacillariophyta & 3 & 11 & 19 & 44 & 95 & 2 & 97 & 37,60 \\
\hline Euglenophyta & 1 & 1 & 2 & 5 & 15 & - & 15 & 5,81 \\
\hline Chlorophyta & 4 & 12 & 19 & 34 & 70 & - & 70 & 27,13 \\
\hline Всего: & 10 & 31 & 59 & 126 & 256 & 2 & 258 & 100 \\
\hline
\end{tabular}


Table.2 Comparative taxonomic structure of algoflora of fish ponds of the Samarkand region

\begin{tabular}{|c|c|c|c|c|c|c|c|}
\hline Reservoirs & Division & Class & Order & Family & Genera & Species & \% \\
\hline $\begin{array}{c}\text { Karasuk } \\
\text { reservoir }\end{array}$ & 5 & 11 & 27 & 46 & 84 & 121 & 46,89 \\
\hline $\begin{array}{c}\text { Akdarya } \\
\text { reservoir }\end{array}$ & 5 & 8 & 24 & 36 & 69 & 83 & 32,17 \\
\hline Pastdargom & 5 & 11 & 27 & 52 & 100 & 166 & 64,34 \\
\hline Kattakurgan & 4 & 9 & 26 & 59 & 98 & 164 & 63,56 \\
\hline Payaryk & 5 & 11 & 25 & 44 & 71 & 106 & 41,08 \\
\hline Shurkul & 5 & 10 & 25 & 40 & 73 & 111 & 41,08 \\
\hline Ishtykhan & 5 & 10 & 21 & 41 & 57 & 89 & 34,49 \\
\hline
\end{tabular}

111 species have been identified in the Shurkul pond. They make up 5 departments, 10 classes, 25 orders, 40 families, 73 genera. They contain such species as: Leibleinia epiphytica, Calothrix brevissima, Cyclotella meneghiniana, Odontidium hyemale, Peridiniopsis quadridens, Euglena gracilis G. A. Klebs, Chlamydomonas reinhardtii, Volvox ehrenberg, Merismopedia elegans, Spirulina princeps, Microcystis protocystis, Oscillatoria planctonica Lemmermann, Fragilaria capucina Desmazières, Ulothrix limnetica Lemmermann in Heering. The algoflora of these fish ponds is formed in the following order: river $\rightarrow$ channel $\rightarrow$ sewage $\rightarrow$ arable land $\rightarrow$ pond; river $\rightarrow$ channel $\rightarrow$ stream $\rightarrow$ pond.

4 divisions of 10 classes, 21 orders of 41 families of 57 genera of 89 species were identified in the algoflora of Ishtykhan fish ponds (Table 2). The following species are found in the algoflora: Cyclostephanos dubius Hustedt, Pantocsekiella kuetzingiana Thwaites, Melosira varians Agardh, Aulacoseira ambigua Grunow, Odontidium anceps Ehrenberg, Fragilaria crotonensis Kitton, Ceratium hirundinella O.F. Müller, Parvodinium pusillum Penard. The formation of algoflora occurs in the following order: rivers $\rightarrow$ fish ponds; rivers $\rightarrow$ channels $\rightarrow$ ditches $\rightarrow$ discharges $\rightarrow$ fish ponds.
The analysis shows that the characteristics, floristic composition, and algocenoses of the studied types of ponds differ depending on the water bodies belonging to each type. This situation depends on the nutrition of the reservoir, the properties of the soil, the water content and the regime of its exchange, a number of environmental factors (temperature, $\mathrm{pH}$, the amount of suspended particles in the water, the content of organic and mineral substances, biogenic elements). The analysis of the peculiarities of the formation of the algoflora of fish ponds in the Samarkand region showed that the algocenoses differ significantly from each other, as well as the floral composition, diversity, and species location of the leading taxa in it. These characteristics include pond power sources, soil properties, pond fertilizers (mineral and organic), operating time, water cycle dynamics, and others. Environmental factors in ponds (temperature, water salinity, $\mathrm{pH}$, suspended particles in water, organic substances) play an important role in its formation.

Due to the high population density around the ponds and the direct discharge of agricultural wastewater into the fish ponds of the Payaryk, Shurkul and Kattakurgan fish ponds, they differ sharply from the algal flora of other types of ponds mentioned above. 
According to taxonomic analysis, this algoflora includes 5 divisions, 10 classes, 33 orders, 60 families, 118 genera, 230 species $(89.14 \%)$. The number of common species for these fish ponds is $116(50.43 \%)$. Common species include Synechococcus elongatus, Merismopedia elegans, Anagnostidinema acutissimum, Lindavia comta, Discostella stelligera, Ctenophora pulchella, Ulnaria capitata, Navicula salinarum, Ceratium hirundinella, Euglena elongatus.

The algal flora of these fish ponds is relatively rich in algae of other studied types of ponds due to their feeding on various water sources, relatively high and moderate water temperatures, and almost complete absence of water exchange in the ponds.

\section{Acknowledgments}

Thanks to Dr. Y. Tashpulatov (Head of the Department of Fundamental Sciences of the Samarkand branch of Tashkent State Agrarian University) for his help in determining the species composition and systematization of algae, and to Dr. B. Meiliev (Associate Professor, Samarkand State University) for his help in compiling a map of the studied area.

\section{References}

Gollerbakh M. M., Polyansky V. I. 1951. Keys to freshwater algae of the USSR. Issue 1. General part. Freshwater algae and their study. - M.: Soviet science. $350 \mathrm{p}$.

Hegewald E. 2005. Revision of the genus Desmodesmus (Sphaeropleales, Scenedesmaceae) species with lateral spines. 2. The multi-spined to spineless taxa // Algological Studies.- Vol. 116. - pp. 1-38.

Krammer K. 2004. Bacillariophyceae Teil: Achnanthaceae, Kritische Ergänzungen zu Navicula (Lineolatae),
Gomphonema

Gesamtliteraturverzeichnis.

Süßwasserflora von Mitteleuropa. Spektrum Akademischer Verland Heidelberg. - Bd. 2 (4). - 468 p.

Kulikovskiy M. S. Gluschenko A. M., Genkal S.I., Kuznetsova I.V. 2016. Identification book of Diatoms from Russia. - Yaroslavl: Filigran. -804 p.

Komárek J., Kaštovský J., Mareš J. \& Johansen J. R. 2014. Taxonomic classification of cyanoprokaryotes (Cyanobacterial genera) 2014, using a polyphasic approach. - Preslia 86: pp. 295-335.

Schmidt V. M. 1974. Quantitative indicators in comparative floristry // Botan. zhurn. - Moscow. Volume 59. - No. 7. pp. $929-940$.

Lange-Bertalot H., Bak M., Witkowski A. 2011. Eunotia and some related genera. - Diatoms of Europe. - Vol. 6. $-747 \mathrm{p}$.

Tashpulatov Y. Sh. 2018. Taxonomic Analysis of Algoflora of the Akdarya Reservoir (Basin of the Zarafshan River, Uzbekistan). Hydrobiological Journal. Vol.54, pp. 49-54. DOI:10.1615/HydrobJ.v54.i1.50.

Tashpulatov Y. Sh., Kobulova B. B. 2020. Environmental Features Formation of Algoflora Middle Flow Zarafshan River (Uzbekistan). International Journal of Scientific and Technological Research, Vol.6, No.7. pp. 85-90. DOI: 10.7176/JSTR/6-07-09.

Thomas Cavalier-Smith. 2016. Higher classification and phylogeny of Euglenozoa // European Journal of Protistology Department of Zoology, University of Oxford, South Parks Road, Oxford. 56. pp. 250-276.

Teil, Krammer K., Lange-Bertalot H. 2004. Süßwasserflora von Mitteleuropa. Spektrum Akademischer Verland Heidelberg. - Bd. 2 (4). - 468 p. 


\section{How to cite this article:}

Shavkat Shukhratovich Shernazarov. 2021. Eco-Alcocenoses of Fish Ponds in the Samarkand Region and its Ways of Formation. Int.J.Curr.Microbiol.App.Sci. 10(07): 337-343. doi: https://doi.org/10.20546/ijcmas.2021.1007.036 